\title{
4. INTERSTITIAL WATER STUDIES, LEG 15 - CHEMICAL AND ISOTOPIC COMPOSITION OF GASES FROM CARIACO TRENCH SEDIMENTS ${ }^{1}$
}

\author{
Graeme L. Lyon, Institute of Nuclear Sciences, Department of Scientific and Industrial Research, Lower Hutt, New Zealand
}

\section{INTRODUCTION}

Site 147 of Leg 15 of the JOIDES program, at $10^{\circ} 42.65^{\prime} \mathrm{N}, 65^{\circ} 10.46^{\prime} \mathrm{W}$, was drilled in the Cariaco Trench off the coast of Venezuela. Four holes were drilled in 882 meters of water for an intensive geochemical study of the pore fluids in the sediments of this anaerobic basin. From Holes $147,147 \mathrm{~B}$, and $147 \mathrm{C}$, ten gas pockets were sampled using the Horowitz-Takahashi device, at core depths between 45 and 180 meters. These samples were taken to the Lamont-Doherty Geological Observatory for division into aliquots for analysis.

\section{ANALYTICAL METHODS}

The gas samples were received in this laboratory in glass breakseals containing approximately $5 \mathrm{ml}$ of gas at $72 \mathrm{~cm}$ $\mathrm{Hg}$ pressure. After attaching to a vacuum line, the breakseal was cooled in liquid oxygen, then broken and the uncondensed gases were removed using a Toepler pump. This uncondensed gas, which was predominantly methane, together with any traces of $\mathrm{H}_{2}, \mathrm{~N}_{2}$, or $\mathrm{O}_{2}$ that may have been present, was then circulated through a copper/copper-oxide furnace at $800^{\circ} \mathrm{C}$ (Hulston and McCabe, 1962) and the oxidation products, water and carbon dioxide, were frozen into liquid-oxygen-cooled traps. No noncondensable gas remained.

The traps were then replaced by ethanol-dry ice mixtures, and the carbon dioxide distilled into a manometer, measured, and then transferred to a bottle for subsequent mass spectrometric analysis for ${ }^{13} \mathrm{C}$. The water from the combustion of methane was then distilled into a small bottle. Subsequently, this water was converted to hydrogen gas by passage over heated zinc and the deuterium content of the hydrogen determined by mass spectrometry.

The sample remaining in the original breakseal was then distilled through a dry ice trap to remove water and its volume measured manometrically before transfer to a bottle for subsequent isotopic analysis of the carbon dioxide. If more than a few percent of ethane or hydrogen sulfide had been present, this would have been observed during isotopic analysis.

Mass spectrometry for the ${ }^{13} \mathrm{C} / 12 \mathrm{C}, 18 \mathrm{O} / 16 \mathrm{O}$ and $\mathrm{D} / \mathrm{H}$ ratios was carried out on standard, dual inlet, double collector mass spectrometers. Results measured relative to laboratory standards have been converted to the international standards, $\mathrm{PDB}$ for ${ }^{13} \mathrm{C} / 12 \mathrm{C}$ and $18 \mathrm{O} / 16 \mathrm{O}$ (Craig, $1957)$ and SMOW for $\mathrm{D} / \mathrm{H}$ (Craig, 1961). Values are quoted

\footnotetext{
${ }^{1}$ Contribution No. 519, Institute of Nuclear Sciences, New Zealand.
}

in the per mil $(\%)$ terminology relative to the standards, and have standard deviations of $\pm 0.3^{\circ} \%$ o for $\delta^{13} \mathrm{C}$, and $\pm 3 \%$ for $\delta \mathrm{D}$. Any contributions to $\delta \mathrm{D}$ by ethane or hydrogen are assumed to be negligible.

\section{RESULTS AND DISCUSSION}

The data obtained from the analyses are presented in Table 1. The natural carbon dioxide fraction is seen to generally increase with depth in the sequence. This corresponds with the greater abundance of dolomite in the lower parts of this highly organic dark olive green calcareous clay. Some carbon dioxide samples were too small for isotopic analysis, but in general, at greater depths, both the $\delta 13 \mathrm{C}$ and $\delta 180$ values for the carbon dioxide are nearer zero (on the PDB scale) compared with further up the sequence. However, nonequilibrium exudation of the interstitial water during compaction could account for some of the variation in these isotopic ratios. The $\delta 180$ values, if in equilibrium with Standard Mean Ocean Water (SMOW), indicate water temperatures between 24 and $47^{\circ} \mathrm{C}$ (O'Neil and Adami, 1969), but the isotope values may have re-equilibrated with water during and subsequent to extraction.

The methane isotopic data show carbon that is extremely depleted in ${ }^{13} \mathrm{C}$, as is usual for the products of anaerobic micro-organisms (Rosenfeld and Silverman, $1959)$ and natural marsh gases (Nakai, 1960). This range of $\delta^{13} \mathrm{C}$, between -59 and $-76 \%$, is similar to that found for methane in sediments from the Gulf of Mexico in Leg 10 (I. R. Kaplan, pers. comm.). The deuterium contents of the methane are all essentially identical within the experimental error, with $\delta \mathrm{D}$ values about $-180^{\circ} \%$ on the SMOW scale. This value is within the range, -165 to $-219^{\circ} \%$, that Schiegl and Vogel (1970) have found for methane from German natural gas and from South African coal. Gunter and Musgrave (1971) found lower deuterium concentrations ( $\delta \mathrm{D}$ values -225 to $-272 \%$ ), in geothermal methane collected from Yellowstone National Park.

Bottinga (1969) has calculated fractionation factors for carbon isotopes between various molecular species, including carbon dioxide, methane and water vapor. These could exchange via the reaction $\mathrm{CH}_{4}+2 \mathrm{H}_{2} \mathrm{O} \leftrightharpoons \mathrm{CO}_{2}+4 \mathrm{H}_{2}$. For these samples, the $13 \mathrm{C}$ fractionation between carbon dioxide and methane indicate equilibrium temperatures between $27^{\circ} \mathrm{C}$ and $52^{\circ} \mathrm{C}$. These values do not exceed the expected core temperature $\left(15-20^{\circ} \mathrm{C}\right)$ by more than $40^{\circ} \mathrm{C}$, whereas geothermal gases (Hulston and McCabe, 1962; Lyon and Hulston, 1971) typically show $60^{\circ} \mathrm{C}$ discrepancies between Bottinga's calculated temperatures and the maximum measured bore-hole temperatures. However, for the samples collected below 100 meters in the sediments, methane and carbon dioxide $\delta 13 \mathrm{C}$ values are relatively 
TABLE 1

Isotopic Analysis of Gas Samples

\begin{tabular}{|c|c|c|c|c|c|c|c|}
\hline \multirow{2}{*}{$\begin{array}{l}\text { N.Z. INS } \\
\text { Sample } \\
\text { No. }\end{array}$} & \multirow{2}{*}{$\begin{array}{l}\text { Designation } \\
\text { (DSDP) }\end{array}$} & \multirow{2}{*}{$\begin{array}{l}\text { Depth in } \\
\text { sediment } \\
\text { (m) }\end{array}$} & \multirow[b]{2}{*}{$\% \mathrm{CO}_{2}$} & \multirow{2}{*}{$\begin{array}{c}{ }^{8}{ }^{3} C_{\mathrm{PDB}} \\
\text { in } \\
\mathrm{CO}_{2}\end{array}$} & \multicolumn{2}{|c|}{${ }^{13} \mathrm{C}_{\mathrm{PDB}}$} & \multirow{2}{*}{$\begin{array}{c}8 \mathrm{D}_{\mathrm{SMOW}} \\
\text { in } \\
\mathrm{CH}_{4}\end{array}$} \\
\hline & & & & & $\mathrm{CO}_{2}$ & $\mathrm{CH}_{4}$ & \\
\hline R4069/1 & $15-147-6-4$ & 47 & 1.0 & n.d. & n.d. & -76.3 & n.d. \\
\hline R4069/4 & $15-147$ B- $6-2$ & 51 & 2.4 & n.d. & -2.9 & -67.6 & -179 \\
\hline R4069/5 & $15-147$ B- $7-4$ & 63 & 2.7 & n.d. & -4.2 & -65.2 & -173 \\
\hline R4069/2 & $15-147-10$ & 82 & 3.0 & -2.9 & -.2 .9 & -64.6 & -175 \\
\hline R4069/6 & $15-147 \mathrm{~B}-9-4$ & 83 & 3.7 & -2.2 & -2.2 & -60.8 & n.d. \\
\hline $\mathrm{R} 4069 / 7$ & $15-147$ B-11-3 & 100 & 12.4 & -0.3 & 0.0 & -65.8 & -179 \\
\hline R4069/3 & $15-147-14-3$ & 118 & 4.7 & -3.4 & -1.5 & -59.6 & -179 \\
\hline R4069/8 & $15-147 C-2-2$ & 128 & 13.2 & +0.4 & +0.2 & -65.1 & -181 \\
\hline R4069/9 & $15-147 C-4-4$ & 148 & 11.1 & -0.3 & +0.5 & -64.4 & -183 \\
\hline $\mathrm{R} 4069 / 10$ & $15-147 C-7-3$ & 175 & 7.5 & -0.4 & -0.5 & -64.6 & -176 \\
\hline
\end{tabular}

n.d. $=$ not determined.

more constant, indicating thermodynamic temperatures of 27 to $34^{\circ} \mathrm{C}$. It may be that this reaction, which is known to be very slow, has only allowed equilibrium to be reached in the oldest sediments of this sequence.

The hydrogen/deuterium ratio in the methane could equilibrate with the interstitial water, which can be assumed to have the same composition as SMOW. Dr. J. R. Hulston (personal communication) has revised the calculations of Bottinga (1969), and recalculated equilibrium with liquid water (Merlivat and Nief, 1967). For a methane $\delta \mathrm{D}$ value of $-180^{\circ} \%$, a temperature of $-17^{\circ} \mathrm{C}$ is indicated, differing again by about $30-40^{\circ} \mathrm{C}$ from the expected temperature; however, the $\mathrm{D}$ calculated temperatures are colder, whereas the $\delta 13 \mathrm{C}$ temperatures are warmer.

If chemical and isotope equilibrium in the system $\mathrm{CH}_{4}-\mathrm{H}_{2}-\mathrm{CO}_{2}-\mathrm{H}_{2} \mathrm{O}$ occurred and if the partial pressures of $\mathrm{CH}_{4}, \mathrm{H}_{2}$, and $\mathrm{CO}_{2}$ and the total pressure in the sediment were known, then the calculations of Ellis (1957) could be used to obtain equilibrium temperatures in the sediments. Such thermodynamic equilibrium temperatures, chemical or isotopic, if determined in deep cores, could give the thermal gradient under the ocean floor.

\section{ACKNOWLEDGMENTS}

I wish to thank Dr. C. H. Hendy for suggesting this study, Mrs. M. A. Cox for invaluable technical assistance, and Dr. J. R. Hulston for useful discussions.

\section{REFERENCES}

Bottinga, Y., 1969. Calculated fractionation factors for carbon and hydrogen isotope exchange in the system calcite-carbon dioxide-graphite-methane-hydrogen-water vapour. Geochim. Cosmochim. Acta. 33, 49.
Craig, H., 1957. Isotopic standards for carbon and oxygen and correction factors for mass spectrometry analysis of carbon dioxide. Geochim. Cosmochim. Acta. 12, 133. 1961. Standards for reporting concentrations of deuterium and oxygen-18 in natural waters. Science. 133, 1833 .

Ellis, A. J., 1957. Chemical equilibrium in magmatic gases. Am. Sci. 225, 416.

Gunter, B. D. and Musgrave, B. C., 1971. New evidence on the origin of methane in hydrothermal gases. Geochim. Cosmochim. Acta. 35, 113.

Hulston, J. R. and McCabe, W. J., 1962. Mass spectrometer measurements in the thermal areas of New Zealand. Part 2. Carbon isotopic ratios. Geochim. Cosmochim. Acta. 26, 399.

Lyon, G. L. and Hulston, J. R., 1971. The application of stable isotope measurements to geothermal temperature studies. Presented to the 43rd Congress of the Australian and New Zealand Association for the Advancement of Science, Brisbane, May 1971.

Merlivat, L. and Nief, G., 1967. Fractionnement isotopique lors des changements d'état solide-vapeur et liquidvapeur de l'eau a des temperatures inferieures a $0^{\circ} \mathrm{C}$. Tellus. 19, 122 .

Nakai, N., 1960. Carbon isotope fractionation of natural gas in Japan. J. Earth Sci., Nahoya Univ. 8, 174.

O'Neil, J. and Adami, L. H., 1969. The oxygen isotope partition function ratio and the structure of liquid water. J. Physical Chemistry. 73, 1553.

Rosenfeld, W. D. and Silverman, S. R., 1959. Carbon isotope fractionation in bacterial production of methane. Science. $130,1658$.

Schiegl, W. E. and Vogel, J. C., 1970. Deuterium content of organic matter. Earth and Planetary Sci. Letters. 7, 307. 